\title{
Form-Focused Instruction on Non-English-Majored Undergraduates' Foreign Language Writing
}

\author{
Yougen Lou \\ School of Foreign Studies, Yangtze University \\ Xiaoguang Li (Corresponding author) \\ School of Foreign Studies, Yangtze University \\ E-mail: xglyangtze@126.com
}

Received: April 20, 2018 Accepted: April 25, 2018 Published: April 27, 2018

doi:10.5296/jad.v4i1.13062 URL: https://doi.org/10.5296/jad.v4i1.13062

\begin{abstract}
This paper reviewed a one-term experiment on form-focused instruction (FFI) in teaching foreign (English) writing to 162 first-year non-English-majored undergraduate students majored history, economics, computer, agriculture, plant protection, floriculture and veterinary from Yangtze University as participants. Participants in this study consisted of 81 non-English-majored undergraduate students in the control group (CG) and 81 non-English-majored undergraduate students in the treatment group (TG). The participants in CG were taught by the traditional method: grammar-translation teaching method and the participants in TG were taught by the new teaching method of FFI. The results showed that 1) compared with a teacher-dominated approach for CG, FFI in teaching English writing for TG did a better job in enhancing students' English writing ability; 2) participates in TG hold positive opinions towards FFI in English writing..
\end{abstract}

Keywords: form-focused instruction, non-English-majored undergraduates, English writing

\section{Introduction}

Form-focused instruction has been popular in the world. Form-focused instruction (FFI) is an important role in task-based foreign language teaching. FFI derives from focus on form instruction, first used by Michael Long (1988). Long(1991) defined focus on form as 'overtly draws students' attention to linguistic elements as they arise incidentally in lessons whose overriding focus is on meaning or communication' (pp. 45-46). Focus on form was difference from focus on forms. Focus on forms involves traditional language teaching consisting of the 
presentation and practice of items drawn from a structural syllabus (Ellis, 2016). Long and Ellis, their studies provided the solid foundation for us to further study form-focused instruction. Many researchers have been interested in FFI. Some researchers were interested in the implication of FFI in vocabulary (Beniko \& Krashen, 2004). The researcher (Amber, 2009) was interested in the application of FFI in grammatical level. Some Chinese researchers studied effects of FFI on language learners' lexical growth (Huang, 2009 \& Wang, 2016). Other Chinese researchers studied effects of FFI on learners' oral ability (Gao, 2009 \& Li, 2013) and effects on learners' lexical, grammatical, pronunciation ability via post-task interaction (Wang, 2016). According to Bergmann \& Sams (Bergmann \& Sams, 2012), a flipped classroom can be described as a setting where that "which is traditionally done in class is now done at home, and that which is traditionally done as homework is now completed in class" ( $\mathrm{p}$. 13). The flipped classroom model changes the view of the classroom from being a knowledge station to being a place for student engagement and formative assessment of students' progress (Kang, 2015). Benefits to implementing the flipped classroom model include students learning at their own pace, reinforcing the teacher-student relationship (Bergmann \& Sams, 2012) and students benefitted from the use of technology in learning English (Aljumah, 2012 \& Al-Kathiri, 2015). On the other hand, there are some challenges with accompanying the implementation of the flipped classroom model such as students having difficulty adjusting to being active learners or neglecting to do the out-of-class work (Huelskamp, 2015). Another challenge is that teachers are not willing or capable of changing and adopting the use of technology (Educause Learning Initiativ, 2012).

This paper will try to focus on FFI in the flipped classroom model on non-English-majored undergraduates' foreign (English) writing to answer the following research questions in this study:

1) As a result of FFI in the flipped classroom model, were there any significant differences between CG's and TG's improvement in English writing applied skills and ability?

2) Did participates in TG hold positive opinions towards FFI in the flipped classroom model?

\section{Methodology and Data Collection}

\subsection{Participants}

In February 2017, 162 first-year Non-English-majored Chinese undergraduates majored agriculture, plant protection, floriculture and veterinary from Yangtze University were volunteers in this study. 162 freshmen, taught by the same male instructor during the whole academic term (February 20, 2017 to June 20, 2017), were 82 females and 80 males, their average age 19, Chinese as their first or mother language. All 162 participants taught by the 40-year-old male English writing instructor were divided randomly into two groups: 81 participants as the Control Group (CG) with the traditional grammar-translation teaching method and 81 participants as the Treatment Group (TG) with FFI in the flipped classroom teaching and learning model. Both CG and TG had the similar level of education background, family background, personality and life experiences, which was to say, their overall learning and cognitive abilities were almost equal. 


\subsection{Instruments}

The instruments utilized in this study were tests on English writing applied ability with participants from CG and TG, and interviews with participants from TG on FFI in the flipped classroom model.

\section{English writing applied ability pre-test}

All the 162 non-English-majored undergraduates were attended the English writing applied tests at 14:30-16:30 on February 23, 2017 in one classroom to gain students' scores on English writing applied ability in CG and TG before the experiment. All the 162 non-English-majored undergraduates were required to complete the tests in two hours. The English writing applied ability test materials in this study were taken from June, 2016 National English writing Test 4 (short for CET4), total 710 for CET4.

\section{English writing applied ability post-test}

All the 162 Non-English-majored undergraduates were attended the English writing applied ability tests at 14:30-16:30 on June 20, 2017 in one classroom to gain students' scores changes in English writing applied ability between CG and TG after the experiment. All the 162 non-English-majored undergraduates were required to complete the tests in two hours. The English writing applied ability tests materials were taken from December, 2016 National English writing Test 4 (short for CET4), total 710 for CET4.

\section{Interview}

After the experiment, all 81 participants in TG in this experiment were interviewed via QQ (a kind of on-line instant message service tool in China) lasted two weeks and were required to fill out the following interview questions: 1) Do you think FFI in the flipped classroom model has improved your English writing ability? 2) What are difficulties when you participate in FFI in the flipped classroom in English writing? 3) Do you think FFI in the flipped classroom model in English writing is beneficial to all of you in TG?

\subsection{Data Collection and Analysis}

Two tests on English writing applied skills or ability before the research experiment (February 20, 2017) and two tests on English writing applied skills or ability (June 20, 2017) were conducted to compare scores changes between CG and TG of non-English-majored undergraduate students in the course English writing. Comparison of Means was adopted to compare the two groups of non-English-majored undergraduate students' average scores of their pre-test and post-test on the basis of samples. And the independent sample T-test was adopted to examine if there were significant differences between $\mathrm{CG}$ and TG before the experiment and after the experiment. Also the independent sample T-test was adopted to examine if there were significant differences between male and female graduate students in CG and TG. Interviews were conducted to collect responses from participates in TG on FFI in the flipped classroom. Before the experiment of FFI in the flipped classroom on non-English-majored undergraduate students' English writing was ended, interviews were held from June17, 2017to June30, 2017 via QQ in a teacher office to gain the responses from 
participants in TG on the English writing teaching and learning method of FFI in the flipped classroom model.

\section{Process of FFI in the Flipped Classroom Model in English writing Teaching and Learning}

New Voyage English writing published by SHANGHAI JIAO TONG UNIVERSITY PRESS as the textbook was used in teaching English writing for non-English-majored undergraduates in CG and TG. In the experiment, participants in the control group were instructed by the traditional grammar-translation English writing teaching and learning model (teachers explaining knowledge points and difficult sentences in the passages through grammar-translation method, then students listening to teachers' English writing instruction). However, participants in the treatment group were instructed by FFI in the flipped classroom model. FFI in the flipped classroom model in English writing in this study was divided into three parts. The first part was that participants in TG watched the videos on English writing texts made by the English writing teacher online or downloaded via students' smart phones outside of the flipped classroom to complete the English writing texts learning tasks and self-tested tasks before the class and summary of the texts they learned. The students can communicate with the English writing instructor about the course English writing learning via the communication platform online via QQ or WeChat (a kind of on-line instant message service tool in China) in their smart phones if students want to ask the instructor questions related to English writing. The second part was that in English writing class, the English writing instructor created the English writing teaching and learning environment to organize and guide students learning English writing through independent study, collaborative learning, achievement exchange and reports. 3-4 students can be organized as one group according to their wills to discuss and share their learning, at the same time, to solve their English writing learning questions they met. Then the representative of every group reports his or her group's English writing learning achievement. Inside of the flipped classroom in teaching English writing, the instructor not only organized and guided the students' learning activities but also joined in their discussion to scaffold students' English writing learning. The third part was that outside of FFI in the flipped classroom on English writing, the students needed write their lesson summary and evaluation about their learning in class, and submitted their lesson summary and evaluation online via their smart phones or other mobile devices to their English writing instructor; then students could read the comprehensive evaluation and feedback of their English writing learning from the instructor online via their smart phones or other mobile devices.

\section{Results}

The results in this study included three parts. One part was English writing tests' results of pre-test and post-test between CG and TG. The other part was responses to interviews on FFI in the flipped classroom in English writing teaching and learning from non-English-majored undergraduates in TG.

\subsection{Effects of FFI in the Flipped Classroom Model Instruction and Traditional Instruction on Non-English-Majored Undergraduates' English Writing Performance}


Table 1 showed that non-English-majored undergraduate students' English writing performance from CG and TG before and after the experiment. The results from Table 1 showed tests' scores between CG and TG taught by different English writing teaching methods in pre- tests' scores between CG and TG and their post- tests' scores between CG and TG. In the scores of pre-tests of English writing between the two groups (CG, TG), there was no significant difference $(\mathrm{t}=1.117$., $\mathrm{P}=.267)$ between $\mathrm{CG}(\mathrm{M}=77.568, \mathrm{~S}=11.886)$ and $\mathrm{TG}$ $(\mathrm{M}=77.161, \mathrm{~S}=11.120)$. However, after the experiment, a significant difference $(\mathrm{t}=-2.120$, $\mathrm{P}=.037)$, from the scores of post-tests, was found between the two groups: CG $(\mathrm{M}=78.457$, $\mathrm{S}=10.748)$ and $(\mathrm{M}=79.593, \mathrm{~S}=9.284)$ in the English writing tests. After the instruction of traditional English writing method and FFI in the flipped classroom model in English writing, all the 162 non-English-majored undergraduates' English applied ability mean scores were higher than their English applied ability mean scores before the experiment. However, after the instruction of FFI in the flipped classroom model in English writing, the participants' mean scores of TG $(M=79.593)$ were higher than that of the participants' mean scores of CG $(\mathrm{M}=78.457)$.

Table 1. Results of non-English-majored undergraduates' English writing scores of pre-test and post-test

\begin{tabular}{|c|c|c|c|c|c|c|}
\hline \multirow{2}{*}{ Groups } & \multicolumn{2}{|c|}{$\mathrm{CG}(\mathrm{N}=81)$} & \multicolumn{2}{|c|}{$\mathrm{TG}(\mathrm{N}=81)$} & \multirow{2}{*}{$\mathrm{t}$} & \multirow{2}{*}{$\mathrm{P}$} \\
\hline & $\mathrm{M}$ & $\mathrm{S}$ & $\mathrm{M}$ & $\mathrm{S}$ & & \\
\hline Pre-test & 77.568 & 11.886 & 77.161 & 11.120 & 1.117 & .267 \\
\hline Post-test & 78.457 & 10.748 & 79.593 & 9.284 & -2.120 & $.037 *$ \\
\hline
\end{tabular}

$\mathrm{M}$ stands for Mean; $\mathrm{S}$ stands for standard deviation; $* \mathrm{P}<.05 ; * * \mathrm{P}<.01$.

4.2 Results of Responses of Interviews From non-English-Majored Undergraduates in TG on English Writing Teaching and Learning Through FFI in the Flipped Classroom Model

Before the experiment of FFI in the flipped classroom on non-English-majored undergraduate students' English writing was ended, interviews were held from June2, 2017to June16, 2017 via QQ in a teacher office to gain the responses from participants in TG on the English writing teaching and learning method of FFI in the flipped classroom model. All the 81 participants in TG as volunteers attended interviews to provide their answers to the following three written questions: 1. Do you think FFI in the flipped classroom model in English writing has improved your English writing applied skills and English writing applied ability? 2. Was it difficult for you to apply FFI in the flipped classroom model in your future English learning even work practice? 3. What do you learn about FFI in the flipped classroom model in English writing?

To question 1) Do you think your English writing skills and ability has been improved by the new writing teaching method of FFI in the flipped classroom model in English writing? Among 81 participants in TG, 75 participants $(92.59 \%)$ told that they found their English writing ability was improved after they were trained by FFI in the flipped classroom in English writing. 


\section{$\triangle$ Macrothink}

Only 6 participants $(7.41 \%)$ in TG said that they did not find their English writing ability improved after they were trained by FFI in the flipped classroom in English writing.

To question 2) What are difficulties when you apply FFI in the flipped classroom model in your English writing? Among 81 participants in TG, 69 participants $(85.19 \%)$ said that they could not express their ideas in English in their writing compositions or articles without enough vocabulary; 12 participants $(14.81 \%)$ told that they did not know how to talk to others in the flipped classroom.

To question 3) Do you think all of you in TG are benefited by the new writing teaching method of FFI in the flipped classroom model in your English writing? Among 81 participants in TG, 75 participants $(92.59 \%)$ told that they were benefited from FFI in the flipped classroom model in English writing; only 6 participants (7.41\%) expressed the different opinion: they was not benefited from FFI in the flipped classroom model in English writing, because they had to discuss the topic they did not like.

Table 2. Results of responses of interviews from non-English-majored graduates in TG taught by the new approach

\begin{tabular}{ccccc}
\hline Question & Acceptance & Percentage(\%) & Unacceptance & Percentage(\%) \\
\hline 1 & 75 & 92.59 & 6 & 7.41 \\
2 & 69 & 85.19 & 12 & 14.81 \\
3 & 75 & 92.59 & 6 & 7.41 \\
\hline
\end{tabular}

\section{Discussion}

The authors in this study want to investigate the answers to the two questions. One of the purposes in this study is to investigate if the English writing teaching and learning through FFI in the flipped classroom model can improve non-English-majored undergraduates' English writing applied skills and ability. Improvement of participants' English writing applied skills and ability in TG shows the important role of FFI in the flipped classroom model played for non-English-majored undergraduates' English writing learning.

According to the results in Table 1, we find that participants in this study trained by the different English writing instruction methods: the traditional English writing model for CG and FFI in the flipped classroom model for TG, participants' English writing applied skills and ability scores in two groups (CG and TG) are both improved. However, the TG's scores are higher than that of the CG's, which means that the FFI in the flipped classroom model can improve non-English-majored undergraduates' English writing applied skills and ability. The results in this study agree with findings in the researchers' studies (Gao, 2009; Li, 2013) in improving learners' language applied ability. We think that FFI in the flipped classroom model encourages non-English-majored undergraduates to watch the English writing teaching videos made by the instructor online or downloaded online via their smart phones to complete their learning tasks English writing knowledge self-tested by themselves online mobile learning 


\section{MInstitute Mach $^{m}$}

before the English writing class, and in English writing class, they are organized or guided by their English writing instructor to share what they have learned or to discuss their questions in learning English writing with their classmates in groups in class to get help from the classmates or the instructor, after class they can get their comprehensive English writing evaluation from their instructor. We may find that FFI in the flipped classroom model agrees with the theory of Constructivism to encourage non-English-majored undergraduates learn knowledge by themselves (according to the theory of Constructivism, knowledge is not taught but is learned by the learner himself through constructing the new knowledge on the basis of old knowledge, under certain settings) and FFI in the flipped classroom model, provides students mobile learning English writing in any time, any place and helps from their classmates or their instructor if they met questions in learning English writing, agrees with the theory of Constructivism (with the help of others, such as the teachers or learning partners), and utilizes certain study resources ( such as smart phones, teaching videos, online resource).

81 Non-English-major undergraduates in TG generally holding positive responses for FFI in the flipped classroom model suggests that FFI in the flipped classroom model applied into regular non-English-majored undergraduate students English writing curriculum is a worthy try. Results in this study agree with findings in the study of Hiroyuki Obari and Stephen Lambacher (2015): "students were satisfied with their flipped classroom lessons and motivated by the Blended Learning (BL) environment that incorporated mobile learning"( $\mathrm{p} .433$ ). The FFI in the flipped classroom model is tentative method for non-English-majored undergraduates to learn how to learn English writing. Although 75 participants in TG think FFI in the flipped classroom model has improved their learning English writing, FFI in the flipped classroom English writing teaching and learning model is not beneficial to all 81 participants in TG, so the instructor needs help solve learners' learning difficulties such as how to provide more chances for students to apply the English writing knowledge and how to control themselves in spending time in playing online games. All the 81 participates, they could learn the course at their own pace, time, places without the limitations of class and limited class time, and they could prepare for the course via their smart phones mobile learning in advance to increase the participation in the classroom and strengthen their grasp with English writing knowledge.

\subsection{Limitations and Suggestions for Further Research}

Though the present study has investigated a survey of form-focused instruction among the 81 non-English-majored undergraduate students in English writing teaching and learning, there are still some limitations in the study.

Firstly, time limitation (only 4 months) and other practical restrictions such as the participants in the study consisted of only 162 non-English-majored undergraduate students as the participants from one university are needed to be broadened in further research.

Secondly, the instruments used in this study to investigate the non-English-majored undergraduate students' English writing instruction involve two tests to measure non-English-majored undergraduate students' English writing ability and interviews to gain responses from participants on the new teaching and learning method. The study would be much better, if it were combined with other instruments such as verbal report, observation. 
More instruments should be used in investigating in the further research.

Finally, participants in this study were the non-English-majored undergraduate students in only one university. The study will be better if more participants from other universities can be participated in the experiment.

Despite of the restraints of the study, we hope that it can offer some guidelines for further research of FFI on non-English-majored undergraduate students' English writing.

\section{Conclusion}

This study is a worth try on FFI in the flipped classroom model to non-English-majored undergraduate foreign language (English) writing. We find 1) compared with a teacher-dominated approach for CG, FFI in teaching English writing for TG did a better job in enhancing students' English writing ability; 2) participates in TG hold positive opinions towards FFI in English writing. Taken as a whole, these results in this study would indicate that FFI can effectively be integrated into the language learning curriculum and play a positive role in improving learners' English writing ability.

\section{References}

Aljumah, F. H. (2012). Saudi learner perceptions and attitudes towards the use of blogs in teaching English writing course for EFL Majors at Qassim University. English Language Teaching, 5(1), 100. https://doi.org/10.5539/elt.v5n1p100

Al-Kathiri, F. (2015). Beyond the classroom walls: Edmodo in Saudi secondary school EFL instruction, attitudes and challenges. English Language Teaching, 8(1), 189-204. https://doi.org/10.5539/elt.v8n1p189

Amber, G. R. (2009). Teaching Grammar to Adult English Language Learners: Focus on Form. Center for Applied Linguistics, 4, 1-4.

Beniko, M., \& Krashen, S. (2004). Is form-focused vocabulary instruction worthwhile? A Journal of Language Teaching and Research, 35(2), 179-185.

Bergmann, J., \& Sams, A. (2012). Flip Your Classroom: Reach Every Student in Every Class Every Day. Teaching Theology \& Religion, 17(1), 82-83. https://doi.org/10.1111/teth.12165

Educause Learning Initiativ. (2012). 7 things you should know about flipped classrooms. Retrieved from http://net.educause.edu/ir/library/pdf/ELI7081.pdf

Ellis, R. (2016). Anniversary article Focus on form: A critical review. Language Teaching Research, 20(3) 405-428. https://doi.org/10.1177/1362168816628627

Gao, S. X. (2009). Focus on Form in College English Teaching. English Language Teaching, 2(2), 46-48. https://doi.org/10.5539/elt.v2n2p46

Huang, R. H. (2009). Form-Focused Instruction and Planned Lexical Instruction. Foreign Language World, 3, 33-39.

Huelskamp, D. (2015). Flipping the Collegiate Science Classroom: A Review of the Research. 


\section{Macrothink}

Journal of Asian Development

ISSN 2377-9594 2018, Vol. 4, No. 1

Global Education Journal, 2015(1).

Kang, N. (2015). The comparison between regular and flipped classrooms for EFL Korean adult learners. Multimedia-Assisted Language Learning, 18(3), 41-72. Retrieved from http://journal.kamall.or.kr/wp-content/upload/2015/10/kang-18-3-02.pdf

Li, Q. (2013). The effects of post-task focus on form on Chinese EFL learners' oral performance. Foreign Language Teaching and Research, 45(2), 214-226.

Long, M. (1988). Instructed interlanguage development. In L. Beebe (Ed.), Issues in second language acquisition: Multiple perspectives (pp.115-141). Rowley, MA: Newbury House.

Long, M. (1991). Focus on form: A design feature in language teaching methodology. In K. de Bot, R. Ginsberg, \& C. Kramsch (Eds.), Foreign language research in cross-cultural perspective. Amsterdam: John Benjamins. https://doi.org/10.1075/sibil.2.07lon

Wang, B. L. (2016). An Exploration of Focus on Form in Post-task Peer Interaction at a Chinese University EFL Classroom. Foreign Languages and Their Teaching, 1, 41-49.

\section{Copyright Disclaimer}

Copyright for this article is retained by the author(s), with first publication rights granted to the journal.

This is an open-access article distributed under the terms and conditions of the Creative Commons Attribution license (http://creativecommons.org/licenses/by/4.0/). 